\title{
An Economic Assessment on Conditions for CAPS Adoption in Odisha (India)
}

\author{
S.N. Mishra ${ }^{1}$, B.C. Benupani ${ }^{1}$, T. Masuda $^{3}$, U. Mohapatra ${ }^{1 *}$, P.K. Roul ${ }^{2}$, \\ C. Chan Halbrendt ${ }^{4}$ and Shruti Mohapatra ${ }^{1}$ \\ ${ }^{1}$ Department Agricultural Economics, OUAT, Bhubaneswar, India \\ ${ }^{2}$ Dean Extension Education, OUAT, Bhubaneswar, India \\ ${ }^{3}$ Kinky University, Japan \\ ${ }^{4}$ University of Hawaii, USA \\ *Corresponding author
}

K e y w o r d s
$\begin{aligned} & \text { CAPS, Stochastic frontier } \\ & \text { production function, } \\ & \text { Binary logit model, } \\ & \text { Adoption of farming } \\ & \text { practices, Resource use } \\ & \text { efficiency }\end{aligned}$
Article Info
Accepted:
23 March 2018
Available Online:
10 April 2018

A B S T R A C T
Despite demonstrated environmental and economic benefits, the adoption of Conservation Agriculture (CA) still remains low across smallholder agricultural communities. Adoption of a complex and composite technology such as CAPS (Conservation Agriculture Production System) requires a thorough understanding of site-specific determinants and constraints in the adoption process. In this paper, an Economic Assessment of adoption of CA practices was conducted including: minimum tillage and inter cropping among farmers in the North Central Plateau Zone of Odisha in India using farm and household surveys. The technical efficiency between adopted and non-adopted farmers was compared and the different factors that influence the adoption of CAPS were disentangled using frontier production function and binary logistic models respectively. Survey results indicate that farmers adopting CAPS are more efficient in resource use than framers that do not adopt. Among the variables measured, cropland area, primary occupation and month of stay influence adoption of CAPS. Garrett ranking method was employed for identifying the important constraints for CAPS adoption. Unavailability of labour in peak seasons and high input cost were found to be the major constraints for adoption of CAPS in the study area. Among policy measures suggested, coalitions and partnership among institutions that deals with CA, namely State Government, agricultural university (OUAT) and NGOs, who should work together to promote CAPS in a coordinated way.

\section{Introduction}

\section{CAPS}

Conservation agriculture (CA) is proposed as a strategy to provide stable and high yields of crop production while also conserving and improving the quality of the natural resource base (Dumanski et al., 2006). CA is a set of soil management practices that minimize the disruption of the soil's structure, composition and natural biodiversity. Despite high variability in the types of crops grown and specific management regimes, all forms of conservation agriculture share three core principles. These principals include (1) 
maintenance of permanent or semi-permanent soil cover (using either a previous crop residue or specifically growing a cover crop for this purpose); (2) minimum soil disturbance through tillage (just enough to get the seed into the ground); (3) regular crop rotations to help combat the various biotic constraints. (Cornell University College of Agriculture and Life science). Today, conservation agriculture is promoted worldwide and is largely the product of the collective efforts of a number of previous agricultural movements, including no-till agriculture, agroforestry, green manures/cover crops; direct planting/seeding, integrated pest management, and conservation tillage among many others.

However, CA is distinct from each of these so-called agricultural packages, even as it draws upon many of their core principles. This is because CA uses many of the available technologies concurrently, resulting in agricultural outcomes that many believe to be much greater than the "sum of its parts."CA methods or measures are emphasized from a sustainability point of view and their benefits on agricultural systems that have been noted as highly socially and environmentally beneficial (Kassam et al., 2009).

However, even though the benefits of CA are well known to agricultural development intuitions, long term adoption rates in smallholder farming communities remains low (Giller et al., 2009). In fact, questions still exist about how CA can be best promoted for adoption including what physical and socioeconomic constraints limit CA promotion(Giller et al., 2009). Even though the active involvement of farmers in the process of developing and diffusing a technology might substantially increase adoption rates (Erenstein et al., 2008) more information is needed about site specific factors that limit adoption so that agricultural development can better promote CA.

\section{Study area (Keonjhar, Odisha, India)}

The North Central Plateau Zone (NCPZ) of Odisha, India, is mostly covered by hilly terrain and the soil is eroded due to natural and social factors such as excess runoff water due to sloping land, shifting cultivation in tribal areas, and excess tillage. Tillage, one of the traditional cultivation methods, results in soil moisture loss and consequently reduce yield. Conservation Agriculture Production System (CAPS) seeks to address these issues by providing better soil and water conservation practices including minimum tillage, crop rotation, residual mulching, production of crops like maize, cowpea, black gram etc. CAPS have been an important component in the global effort to reduce the quantity of top soil loss. In addition to the environmental impacts, successful promotion of CAPS has also shown to have economic and social impacts in rural communities. Enrolment of farm land in the CAPS provides more secure income stream and retirement income for some rural land owners.

\section{Location}

\section{Agro ecological and socio economic characteristics in research areas}

Orissa is a state on the eastern seaboard of India, located between 17049 and 220 36' North latitudes and between $81036^{\prime}$ and 870 $18^{\prime}$ East longitudes. It spreads over an area of $1,55,707 \mathrm{sq} \mathrm{km}$. and is broadly divided into four geographical regions, i.e. Northern Plateau, Central River Basins, Eastern Hills and Coastal Plains. The Population of Orissa was about 41 million, making it the 11th most populated state in India (2011 census). It is situated in the Eastern part of the subcontinent and it has $485 \mathrm{~km}$ of coastline stretched across the Bay of Bengal on its east. It receives an average annual rainfall of $1489 \mathrm{~mm}$. Mean annual temperature for the 
state is $26.2^{\circ} \mathrm{C}$. The forest cover in the State constitutes $31.38 \%$ of the geographical area. Odisha is primarily an agrarian economy having nearly $15.4 \%$ contribution to the Gross State Domestic product (GSDP), with 73 percent of the work force engaged in this sector (Odisha Economic Survey 2014-15) ${ }^{7}$.

In terms of ecological conditions for agriculture in Keonjhar, the soil is mostly red throughout the district however there is a small patch of black cotton soil in south and a sizeable strip of alluvial soil in the west. The climate of Keonjhar District is characterized by an oppressively hot summer with high humidity. During the summer, maximum temperature touches around $38^{\circ} \mathrm{C}$. The temperature in the month of December is lowest and hovers at around $11^{\circ} \mathrm{C}$ with some temperatures as low as $7^{\circ} \mathrm{C}$. The average annual rainfall is around $1534.5 \mathrm{mms}$. Keonjhar District comes under two Agro Climatic Zones (ACZ) i.e. East Coast Plains and Hills Region and Eastern Plateau and hills (DACNET). Among the ten Agro Climatic Zones of Odisha, the district comes under North-central Plateau Zone (Fig. 1b). Hence it is suitable for cropping of rice, groundnut, maize, arhar (Kajanus kajun), cole crops wheat, vegetables etc.

\section{Farming situation}

Total Cultivable area in Keonjhar District is 297873 ha (36\% of Geographical Area) which accounts for $53.3 \%$ highlands, $33.5 \%$ medium land and $13.2 \%$ of the low land. Its irrigation potential in Kharif is 81653 ha and in Rabi it is 31,327 ha. The region is mostly dominated by marginal farmers (totaling 103,016 farms) followed by smallholder farmers (totaling 77,025 farms) and big farmers (totaling 33,403 farms). Against this backdrop, we present data collected from marginalized farmers from the North Central Plateau Zone (NCPZ) of Odisha and their farm-based conditions in relation to the adoption of CAPS. Specifically, the study has three main objectives including (1) To compare technical efficiency of farmers adopting CAPS compared to non-adopters; (2) to determine the socio economic determinants of early adopters of hybrid maize and; (3) to identify various constrains in CAPS adoption and suggest suitable policy measures.

\section{Materials and Methods}

\section{Assessing CAPS adoption}

Scientists and researchers have been addressing constraints on CA adoption for the last 40 years. Knowler et al., (2007) gathered and analysed all research done to date to identify reasons that explain adoption compared to non-adopters. In their study, they reviewed 23 studies and detected 9 methods that were used to assess adoption which included: ordinary least squares (OLS), random effects (GLS), binary logistic methods, stepwise regression, linear probability models, multinomial logit models, Cragg model and multiple classification analysis (MCA). Ultimately, the authors concluded that these methods vary and likely influence overall the quality of inferences made about $\mathrm{CA}$ adoption since they included diverse processing and analysis protocols. These findings indicate that there is not one best approach to assess CA adoption.

\section{Statistical layout and design}

\section{Sampling design}

For our study, multi-stage stratified random sampling was used to identify farmers to participate. Literature documented many variants of the technique (e.g. Levy and Lameshow, 1991), with the common feature being the consideration of the size of individual units when performing the random selection. Adoption of minimum tillage, inter 
cropping and cover cropping in a cropping system of Maize and Cow Pea has been considered as CAPS practices among farmers of two CAPS practicing villages (Tentuli and Talachampei). Similarly, two non CAPS practicing villages (Badamahuladiha and Rudhiapada) were selected with conventional farming practices. Twenty farmers from each village comprised the sample size. Ultimately, our sample included 40 adopters and 40 non adopters from these villages.

For this survey, specially designed pre-tested schedules were used to collect household and demographic data as well as socio economic data in the study area. The survey was conducted during the crop year 2014-15 and assisted by 5 numbers of trained enumerators. Apart from primary data, general information about the study area was collected from secondary source i.e. Block office, District Agriculture Office and from internet (http://ordistricts.nic.in) to select our randomized sample of farmers.

\section{Descriptive statistics of study area}

The majority of population in the four sample villages is tribal and practice smallholder farmer subsistence rainfed agriculture. From our sample, the average household age was 47 years and farmers had completed second standard of education. The average household family size was six. The average cultivated area under maize and paddy are 0.44 acre and 1.49 acre respectively, with the corresponding average yield 131.98 and $760.19 \mathrm{~kg}$ annually respectively.

Tools used in comparing technical efficiency of CAPS adopted and nonadopted villages

Villages like Badamahuladiha and Rudhiapada were brought under CAPS programme during last part of the year 2014 and no tangible benefits occurred to the farming households out of the programme given the short turnaround time for analysis. Most of the farmers were using conventional farming practices. Thus the above villages were treated as non-adopters. In contrast Tentuli and Talachampei villages are practicing CAPS since last 4 years and are treated as adopters of CAPS.

For the current study the two newly CAPS adopted villages namely Badamahuladiha and Rudhiapada were treated as non CAPS adopted since benefits have not yet accrued to the households and Tentuli and Talachampei as CAPS adopted villages. As (Badamahuladiha and Rudhiapada) have started adopting CAPS practices during the year 2014, therefore they can be considered as non-adopters. In contrast, villages Tentuli and Talachampei have been practicing CAPS since last 4 years.

Following the Stochastic Frontier Production Model we assume that the inefficiency effects are independently distributed and $\mu_{\text {it }}$ arises by truncation at zero of the normal distribution (Kumbhakar and Lovell, 2000).

The stochastic frontier involved two random components, one associated with the presence of technical inefficiency and the other being a traditional random error.

As stated by Meeusen et al., (1977) and Aigner et al., (1977), the model is specified as below.

$\ln y=\ln f(x)-u+v$ with $u \geq 0$

Where $-\mathrm{u} \leq 0$ accounts for technical efficiency and ' $v$ ' accounts for statistical noise. The model can be rewritten (Coelli et al., 2005, p.243),

$Y=f(x) e^{-u} e^{v}$ 
Output oriented technical efficiency are usually as the ratio between the observed output and (the individual) stochastic frontier output (Coelli et al., 1995).

$$
T E=\frac{Y}{f(x) e V}=\frac{f(x) e^{-u} e^{v}}{f(x) e^{v}}=e^{-u}
$$

$\mathrm{v} \sim \mathrm{N}\left(0, \delta_{\mathrm{n}}{ }^{2}\right) ; \mathrm{u} \sim \mathrm{N}^{+}\left(\mathrm{u}, \delta_{\mathrm{u}}{ }^{2}\right)$

\section{Variables}

The variables in our study include, the dependent variable in terms of yield in quintals (Yield of maize + Maize equivalent Yield of the intercrop cowpea, Maize equivalent Yield $=$ Yield of Cowpea/Price of Maize * Price of Cowpea +Yield of Maize) while the independent variables include; Area (Acre), Seed (Kg), Fertilizer (Kg), Labour (Man Day) and FYM (Kg).

Tools used in determining socio-economic determinants of early adopters

\section{Empirical methods}

The binary logistic model is used to predict a binary response based on one or more predictor variables. That is, it is used in estimating the parameters of a qualitative response model. Adoption of CA technologies has been defined in several ways depending on the nature of the technology in question. In this study, adoption refers to the decision by a farmer to use a particular CA technology or practice, a definition similar to that used by Feder et al., (1985). The extent of adoption is measured as the proportion of area that the farmer commits to a particular technology.

\section{Empirical adoption decision models}

In this study, we model the adoption and use intensity of three dominant CA technologies observed in the study area, namely no tillage, crop rotation and cover cropping. Factors considered important in determining their individual or joint adoption are discussed in the following sections (Table 1).

\section{Choice of variables for the empirical models}

Table 3 describes all variables that have been used in the empirical model. Due to resource limitations and gender discrimination in extension message delivery female farmers are less likely to adopt CA technologies (Langyintuo and Mungoma, 2008). CA technologies are knowledge-intensive and hence complex technologies (Wall, 2007); therefore education level of household head is hypothesized to be positively associated with adoption. The likely effect of age of farmer on adoption decisions has shown mixed results as a predictor variable (Langyintuo, 2003). FAO (2001)claim that age and farmers' experience are very difficult factors to link with adoption of C.A. Adesina and Zinnah (1993), noted that younger farmers are more amenable to change old practices than older farmers because they tend to be more aware and knowledgeable about new technologies. Conversely, older farmers may be in a better position to adopt new technologies due to their comparative advantage in terms of capital accumulated, number of extension contacts/visits, creditworthiness etc. (Langyintuo and Mekuria, 2005). Farmers with larger families are more likely to be better resource endowed than otherwise and hence more willing to try out new technologies. But in general, the impact of farm size on adoption is ambiguous. The slope of the farm is presumed to be positively associated with adoption of CA technologies (Tizale, 2007) due to its influence on erosion. Lack of access to cash or credit may hamper smallholder farmers from adopting new technologies that require initial investments (Feder et al., 1985; Doss, 2004) 
and therefore its access is assumed to be positively associated with adoption.

So off farm income is also taken as variable for adoption.

Factors adopting CAPS was carried out employing Logit Regression of the following form.

$$
P(Y)=\frac{1}{-\cdot-e^{-z}}
$$

$Z=\beta_{0}+\beta_{1} D_{1}+\beta_{2}$ monthstay $+\beta_{3} D_{2}+\beta_{4} \mathrm{MI}+$ $\beta_{5} \mathrm{OI}+\beta_{6}$ cropland $+\beta_{7}$ techasst $+\delta$

Where,

$\mathrm{D}_{1}=$ Education level

$\mathrm{D}_{1}=1$ If educated

$\mathrm{D}_{1}=0$ Otherwise

Month of stay= Month of stay in the village /Farm (Months)

$\mathrm{D}_{2}=$ Primary Occupation

$\mathrm{D}_{2}=1$ If Farming as main occupation

$\mathrm{D}_{2}=0$ Otherwise

$\mathrm{MI}=$ Migration Income (Rupee)

$\mathrm{OI}=$ Off Farm Income (Rupee)

$\mathrm{R}^{2}$ of the model was calculated by the following formulae. (Statistical package used - SPSS 16.0).

$$
\mathrm{R}^{2}=\quad \frac{\text { Model chi-square }}{\text { Original }-2 \mathrm{LL}}
$$

The farmers who put 50 percent or more area under hybrid maize cultivation were considered as adopters otherwise non adopters. Pre-tested schedules are used to collect data in this survey.
Garrett ranking for constraint analysis

On the basis of the outcome of the study, only 10 selected constraints have been used in the final survey. Sample farmers have been called to assess each constraint on its own significance.

Each respondent was instructed to indicate the importance of the influencing constraints by giving rank 1 to the most important constraint, rank 2 to the second important constraint and so on.

Based on the ranks assigned by the sample farmers, the order of important constraints influencing the adoption of CAPS in the study area was calculated. To find the most significant constraint influencing the CAPS adoption, Henry Garrett's Ranking Technique was employed. It is calculated as percentage score and the scale value is obtained by employing Scale Conversion Table given by Henry Garrett (Jayabalan, 1998) (Table 2).

The Percentage Score is calculated as

$100\left(\mathrm{R}_{\mathrm{ij}}-0.5\right)$
Percentage Score $=$-------------
$\mathrm{N}_{\mathrm{j}}$

Where, $R_{i j}$ is Rank given for $i^{\text {th }}$ item $j^{\text {th }}$ individual $\mathrm{N}_{\mathrm{j}}$ is Number of items ranked by $\mathrm{j}^{\text {th }}$ individual

The score value (fx) is calculated for each factor by multiplying the number of respondents (f) with respective scale values (x). The total scores are found by adding the score values (fx) of each rank for every constraint.

The mean score is then calculated to know the order of preference given by the respondents for the constraints. Based on the mean score, the overall ranks are assigned for each. 


\section{Results and Discussion}

Technical efficiency of farmers adopting CAPS compared to non adopters using frontier production function

\section{CAPS adopted villages}

The maximum likelihood estimates for the production function was used to explain the technical efficiency of individual farmers as well as system efficiency aside from the influence of input used on crop output in CAPS adopted villages. The parameters of the frontier production function were estimated using R.3.1.1 (Arne Henningsen, 2014).

Final maximum likelihood estimates of frontier production function (Table 4) shows that coefficient for the variables of seeds, Farm Yard Manure (FYM), Di Ammonium Phosphate (DAP), Muriate of Potash (MOP) and urea were found to be positive and significantly influence farm output of the respondents. However associated coefficients of area under food grains and labour were not significant even at 10 level significance and were negatively correlated. It can be implied that seed, fertilizer (DAP, MOP, Urea) and FYM positively impacts production of food grain. Households having more cropland area not able to carry out farm operation in time which leads to decrease in crop output.

The value of the sigma square $\left(\delta^{2}\right)$ and gamma (variance ratio) were highly significant indicating good fit and correctness of distributional form composite error term in the model. All the estimated coefficients are less than one, indicating that input allocation is in stage II of the production function.

The estimated coefficient of farm size is negative and non-significant indicating that increase in farm size doesn't enhance productivity (Fig. 2).
The estimated coefficient of application of FYM is positive and statistically significant, indicating that food crop output among the respondent is inelastic to change in quantity of FYM application. One percent increase in quantity of fertilizer application would bring about increase in output but at a decreasing rate and in the rational stage of production.

The summary of the technical efficiency scores for the respondent is presented in Table 6.

Proportion of variance due to inefficiency was estimated to be around 1, implying that nearly $100 \%$ of the inefficiency was explained by the stochastic frontier model. Since the value of $\Upsilon$ approaches 1, also remain one side error, where $\mathrm{U}_{\mathrm{i}}$ dominated the symmetry error distribution. It corroborates the findings of Hidayal et al., (2013).

The LR method compares the stochastic frontier model with corresponding OLS model (i.e. a model $\Upsilon$ equals to zero) and it follows Chi-square distribution. Since the value of Chi-square is significant the null hypothesis of no inefficiency is rejected. This clearly implied that OLS model is rejected in favor of the stochastic frontier model i.e. there is significant technical inefficiency.

The mean technical Efficiency is 0.71, implying that the farmers were $71 \%$ technically efficient, leaving a $29 \%$ potential enhancement. The best farmer had $99 \%$ technical efficiency while the worst farmer has a technical efficiency of $36 \%$.

The minimum values shows the most inefficient farmers and vice versa. If the inefficient farmers were enabled to reach the maximum level of efficiency, the cost they may save are up to $63.64 \%$ (1-0.36/0.99). Similarly the farmers would enable save $28.29 \%$ of their usual production cost (Table $6)$. 
Fig.1a Keonjhar in Odisha, India

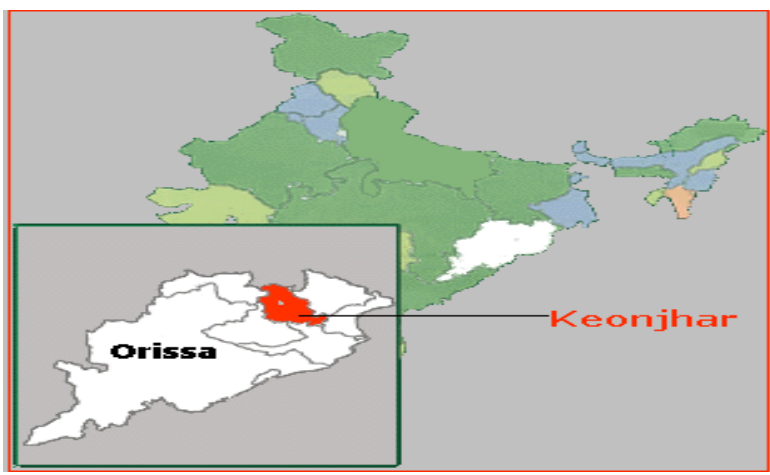

Fig.1b Agroclimatic zones of Odisha

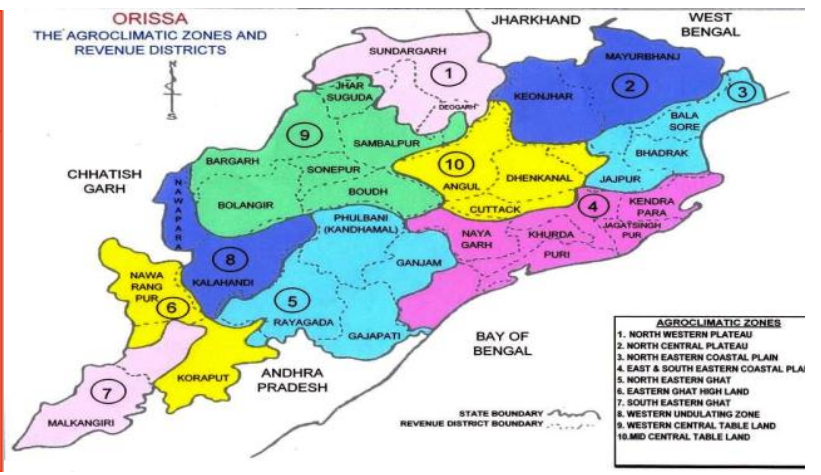

Fig.2 Efficiency percent distribution of CAPS adopted farmers

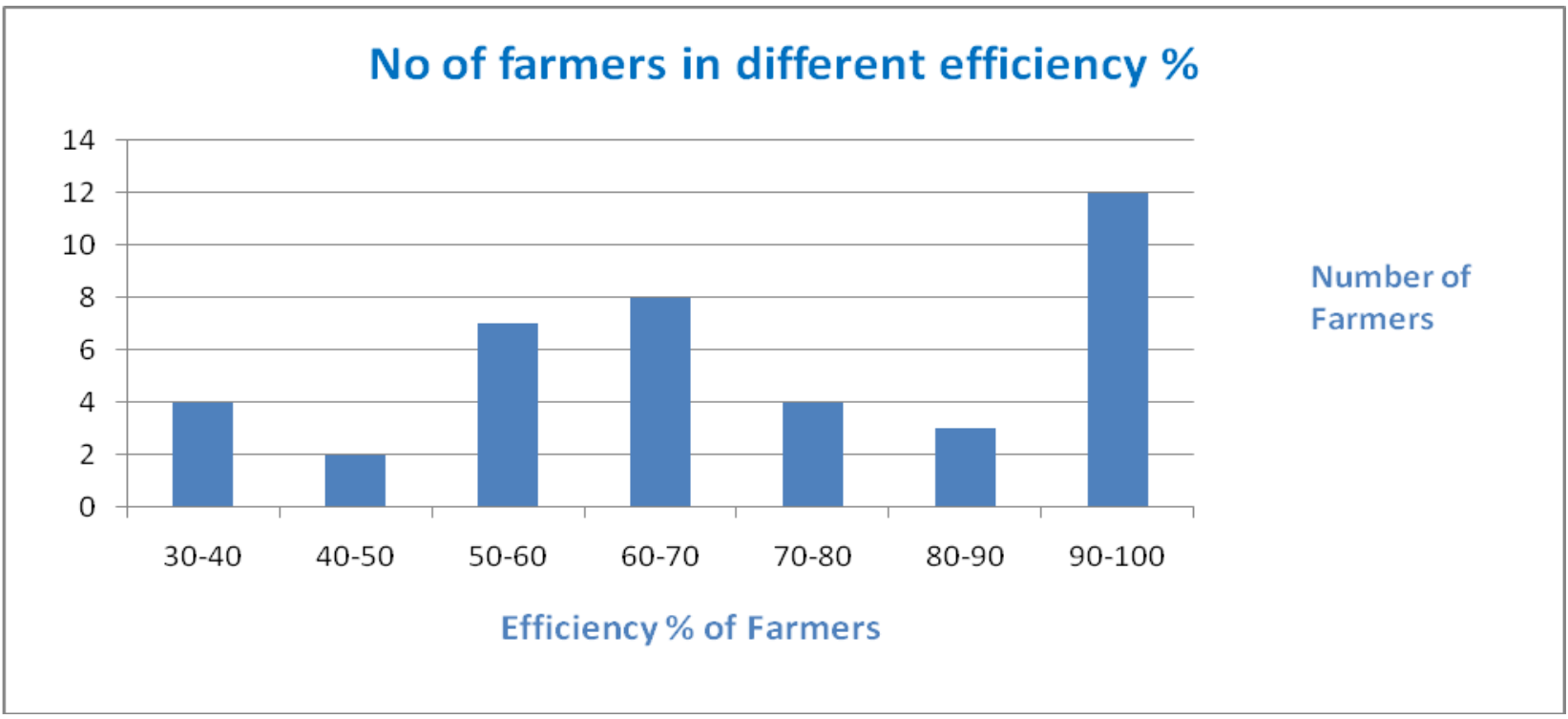

Fig.3 Efficiency percent distribution of non CAPS adopted farmers

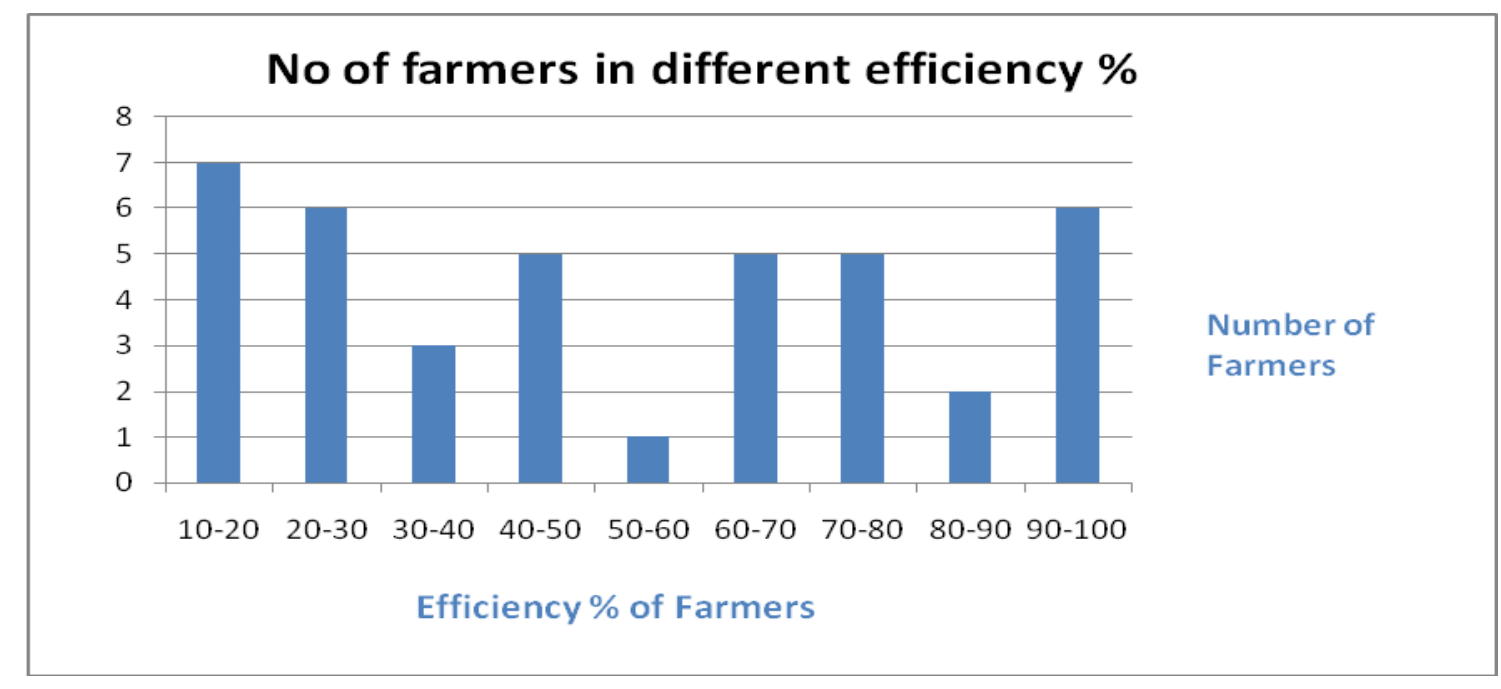


Table.1 Key socio demographic characteristics of the villages are shown in the table below

\begin{tabular}{|c|c|c|c|c|c|c|}
\hline \multirow{2}{*}{$\begin{array}{l}\text { Sl. } \\
\text { No }\end{array}$} & \multirow[t]{2}{*}{ Parameters } & Badamahuladiha & Rudhiapada & Tentuli & Talachampei & \multirow{2}{*}{$\begin{array}{l}\text { Overall } \\
\text { Mean }\end{array}$} \\
\hline & & Mean & Mean & Mean & Mean & \\
\hline 1 & HH age & 49 & 47 & 42 & 48 & 47 \\
\hline 2 & HH grade completed & 2 & 1 & 2 & 3 & 2 \\
\hline 3 & Family size & 5 & 7 & 6 & 6 & 6.00 \\
\hline 4 & Maize area(Acre) & 0.4735 & 0.4635 & 0.357 & 0.483 & 0.44 \\
\hline 5 & Yield of Maize(kg) & 49.525 & 105.15 & 184.25 & 189 & 131.98 \\
\hline 6 & Paddy Area(Acre) & 1.595 & 1.315 & 1.66 & 1.38 & 1.49 \\
\hline 7 & Yield of Paddy(kg) & 900 & 847.75 & 767.5 & 525.5 & 760.19 \\
\hline 8 & Major Staple crop & Rice, Maize & Rice, Maize & Rice, Maize & Rice, Maize & \\
\hline
\end{tabular}

Table.2 Garrett ranking for constraints analysis

\begin{tabular}{|c|c|c|c|c|}
\hline Sl No & Constrains & $\begin{array}{c}\text { Total } \\
\text { Garrett } \\
\text { Score }\end{array}$ & $\begin{array}{c}\text { Mean Garrett } \\
\text { Score }\end{array}$ & Rank \\
\hline 1 & Input prices are increasing & 3580 & 89.5 & 2 \\
\hline 2 & Non availability of labour & 3623 & 90.575 & 1 \\
\hline 3 & $\begin{array}{l}\text { Non availability of quality seed and other } \\
\text { agricultural inputs in time }\end{array}$ & 2871 & 71.775 & 3 \\
\hline 4 & No irrigation scheme & 2786 & 69.65 & 4 \\
\hline 5 & Vulnerability to natural calamities & 2602 & 65.05 & 5 \\
\hline 6 & Lack of training and exposure on CAPS & 2576 & 64.4 & 7 \\
\hline 7 & Lack of Risk management and insurance coverage & 744 & 18.6 & 10 \\
\hline 8 & Alcoholism and high degree of backwardness & 2494 & 62.35 & 8 \\
\hline 9 & Problem of stray cattle and wild animals & 1792 & 44.8 & 9 \\
\hline 10 & $\begin{array}{l}\text { Lack of storage, credit and marketing facilities } \\
\text { among maize farmers }\end{array}$ & 2594 & 64.85 & 6 \\
\hline
\end{tabular}

Table.3 Role of stakeholders in enhancing the livelihood and food security of smallholder farmers in the District of Kendujhar, Odisha State, India

\begin{tabular}{|c|c|}
\hline Stakeholder & Roles \\
\hline Policymakers/ Government & $\begin{array}{l}\text { - Strengthen extension services to rural farming areas } \\
\text { Subsidize seeds, fertilizers and other inputs for the initial stages } \\
\text { of implementing conservation agriculture (CA) practices } \\
\text { - } \quad \text { Provide low cost loans and insurance }\end{array}$ \\
\hline Seed Suppliers & $\begin{array}{l}\text { Provide training on benefits and use of commercial seed varieties } \\
\text { Work with agricultural managers and extension to focus on seeds } \\
\text { that utilize intercropping }\end{array}$ \\
\hline Extension & $\begin{array}{l}\text { Disseminate the benefits/costs of CA practices } \\
\text { Provide long-term demonstration plots comparing yield and soil } \\
\text { effects for conventional and CA practices }\end{array}$ \\
\hline
\end{tabular}


Table.4 Final maximum likelihood estimates of frontier production function of CAPS adopted village

\begin{tabular}{|c|c|c|c|c|}
\hline & Estimate & Std. Error & Z value & $\operatorname{Pr}(>|z|)$ \\
\hline (Intercept) & $6.0945 \mathrm{e}+00$ & $1.8992 \mathrm{e}-01$ & $3.2090 \mathrm{e}+01$ & $<2.2 \mathrm{e}-16 * * *$ \\
\hline Logma & $-3.2957 \mathrm{e}-02$ & $2.9474 \mathrm{e}-02$ & $-1.1182 \mathrm{e}+00$ & 0.263481 \\
\hline Logms & $7.2903 \mathrm{e}-01$ & $7.8096 \mathrm{e}-02$ & $9.3351 \mathrm{e}+00$ & $<2.2 \mathrm{e}-16 * * *$ \\
\hline Logfym & $3.1213 e-02$ & $6.0785 \mathrm{e}-03$ & $5.1349 e+00$ & $2.823 \mathrm{e}-07 * * *$ \\
\hline logdap & $4.4917 \mathrm{e}-02$ & $1.3886 \mathrm{e}-02$ & $3.2347 e+00$ & $0.001218 * *$ \\
\hline logmop & $2.5368 \mathrm{e}-02$ & $7.8251 \mathrm{e}-03$ & $3.2419 \mathrm{e}+00$ & $0.001187 * *$ \\
\hline $\log u$ & $5.0554 \mathrm{e}-02$ & $1.1132 \mathrm{e}-02$ & $4.5415 e+00$ & $5.585 \mathrm{e}-06 * * *$ \\
\hline logl & $-9.0239 \mathrm{e}-02$ & $5.3006 \mathrm{e}-02$ & $-1.7024 e+00$ & 0.088675 \\
\hline sigmaSq & $3.6187 \mathrm{e}-01$ & $4.7063 e-02$ & $7.6891 \mathrm{e}+00$ & $1.482 \mathrm{e}-14 * * *$ \\
\hline gamma & $1.0000 \mathrm{e}+00$ & $1.0987 \mathrm{e}-07$ & $9.1015 e+06$ & $<2.2 \mathrm{e}-16 * * *$ \\
\hline sigmaSqU & $3.6187 \mathrm{e}-01$ & $4.7063 e-02$ & $7.6891 \mathrm{e}+00$ & $1.482 \mathrm{e}-14 * * *$ \\
\hline sigmaSqV & $3.6187 \mathrm{e}-09$ & $3.9650 \mathrm{e}-08$ & $9.1300 \mathrm{e}-02$ & 0.927281 \\
\hline sigma & $6.0156 \mathrm{e}-01$ & $3.9118 \mathrm{e}-02$ & $1.5378 \mathrm{e}+01$ & $<2.2 \mathrm{e}-16 * * *$ \\
\hline sigmaU & $6.0156 \mathrm{e}-01$ & $3.9118 \mathrm{e}-02$ & $1.5378 \mathrm{e}+0$ & $<2.2 \mathrm{e}-16 * * *$ \\
\hline sigmaV & $6.0156 \mathrm{e}-05$ & $3.2956 \mathrm{e}-04$ & $1.8250 \mathrm{e}-01$ & 0.855165 \\
\hline lambdaSq & $1.0000 \mathrm{e}+08$ & $1.0987 \mathrm{e}+09$ & $9.1000 \mathrm{e}-02$ & 0.927480 \\
\hline lambda & $1.0000 \mathrm{e}+04$ & $5.4936 \mathrm{e}+04$ & $1.8200 \mathrm{e}-01$ & 0.855559 \\
\hline varU & $1.3150 \mathrm{e}-01$ & NA & NA & NA \\
\hline sdU & $3.6263 e-01$ & NA & NA & NA \\
\hline gammaVar & $1.0000 \mathrm{e}+00$ & NA & NA & NA \\
\hline
\end{tabular}

Significant codes: 0 '***' 0.001 ' $* *$ ’ 0.01 ' $*$ ’ 0.05 ', 0.1 ' ' 1

log likelihood value: -2.270575 , DF- $1, \chi^{2}=9.3722, \operatorname{Pr}(>$ Chisq $)=0.001101 * *$

Mean efficiency: 0.7120555 i.e. $71.20 \%$

Table.5 Final maximum likelihood estimates of frontier production function of non CAPS adopted villages

\begin{tabular}{|c|c|c|c|c|}
\hline & Estimate & Std.Error & Z value & $\operatorname{Pr}(>|\mathrm{z}|)$ \\
\hline (Intercept) & $5.2714 e+00$ & $6.6005 \mathrm{e}-01$ & 7.9864 & $1.389 \mathrm{e}-15 * * *$ \\
\hline Logma & $7.1030 \mathrm{e}-01$ & $3.9417 \mathrm{e}-02$ & 18.0202 & $<2.2 \mathrm{e}-16 * * *$ \\
\hline Logms & $1.1628 \mathrm{e}-01$ & $9.9056 \mathrm{e}-02$ & 1.1739 & 0.2404 \\
\hline Logfym & $-1.0513 \mathrm{e}-02$ & $2.5378 \mathrm{e}-02$ & -0.4142 & 0.6787 \\
\hline Logdap & $-2.3074 \mathrm{e}-03$ & $2.8823 e-02$ & -0.0801 & 0.9362 \\
\hline Logmop & $6.6254 \mathrm{e}-02$ & $1.6763 \mathrm{e}-02$ & 3.9523 & $7.740 \mathrm{e}-05 * * *$ \\
\hline Logu & $-2.8140 \mathrm{e}-02$ & $2.6543 e-02$ & -1.0601 & 0.2891 \\
\hline Logl & $-3.3313 e-02$ & $1.7045 \mathrm{e}-01$ & -0.1954 & 0.8451 \\
\hline sigmaSq & $1.0106 \mathrm{e}+00$ & $1.8805 \mathrm{e}-01$ & 5.3740 & $7.700 \mathrm{e}-08 * * *$ \\
\hline gamma & $1.0000 \mathrm{e}+00$ & $1.3600 \mathrm{e}-06$ & 735278.6854 & $<2.2 \mathrm{e}-16 * * *$ \\
\hline sigmaSqU & $1.0106 \mathrm{e}+00$ & $1.8805 \mathrm{e}-01$ & 5.3740 & $7.700 \mathrm{e}-08 * * *$ \\
\hline sigmaSqV & $1.0106 \mathrm{e}-08$ & $1.3739 \mathrm{e}-06$ & 0.0074 & 0.9941 \\
\hline sigma & $1.0053 \mathrm{e}+00$ & $9.3531 \mathrm{e}-02$ & 10.7481 & $<2.2 \mathrm{e}-16 * * *$ \\
\hline sigmaU & $1.0053 e+00$ & $9.3531 \mathrm{e}-02$ & 10.7480 & $<2.2 \mathrm{e}-16 * * *$ \\
\hline sigmaV & $1.0053 \mathrm{e}-04$ & $6.8337 \mathrm{e}-03$ & 0.0147 & 0.9883 \\
\hline lambdaSq & $1.0000 \mathrm{e}+08$ & $1.3600 \mathrm{e}+10$ & 0.0074 & 0.9941 \\
\hline lambda & $1.0000 e+04$ & $6.8001 e+05$ & 0.0147 & 0.9883 \\
\hline varU & $3.6722 \mathrm{e}-01$ & NA & NA & NA \\
\hline sdU & $6.0599 \mathrm{e}-01$ & NA & NA & NA \\
\hline gammaVar & $1.0000 \mathrm{e}+00$ & NA & NA & NA \\
\hline
\end{tabular}

Significant codes: 0 '***' 0.001 '**' 0.01 ' $*$ ’ 0.05 ', 20.1 ' ' 1

$\log$ likelihood value: $-32.85118, \mathrm{DF}-1, \chi^{2}=13.307, \operatorname{Pr}(>$ Chisq $)=0.0001322 * * *$

Mean efficiency: 0.5212769 i.e. $52.127 \%$

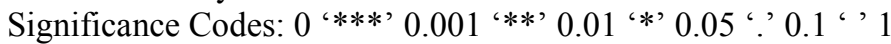


Table.6 Efficiency scores of CAPS adopted farmers

\begin{tabular}{|c|c|c|}
\hline Efficiency Level & Frequency & Percentage \\
\hline $30-40$ & 4 & $10.00 \%$ \\
$40-50$ & 2 & $5.00 \%$ \\
$50-60$ & 7 & $17.50 \%$ \\
$60-70$ & 8 & $20.00 \%$ \\
$70-80$ & 4 & $10.00 \%$ \\
$80-90$ & 3 & $7.50 \%$ \\
$90-100$ & 12 & $30.00 \%$ \\
\hline Total & 40 & $100 \%$ \\
\hline
\end{tabular}

Table.7 Efficiency scores of non CAPS adopted farmers

\begin{tabular}{|l|l|l|}
\hline Efficiency Level & Frequency & Percentage \\
\hline $10-20$ & 7 & $17.50 \%$ \\
\hline $20-30$ & 6 & $15.00 \%$ \\
\hline $30-40$ & 3 & $7.50 \%$ \\
\hline $40-50$ & 5 & $12.50 \%$ \\
\hline $50-60$ & 1 & $2.50 \%$ \\
\hline $60-70$ & 5 & $12.50 \%$ \\
\hline $70-80$ & 5 & $12.50 \%$ \\
\hline $80-90$ & 2 & $5.00 \%$ \\
\hline $90-100$ & 6 & $15.00 \%$ \\
\hline Total & 40 & $100 \%$ \\
\hline
\end{tabular}

Table.8 Classification table of Logit Regression

\begin{tabular}{|c|c|c|c|c|}
\hline \multicolumn{2}{|l|}{ Observed } & \multicolumn{3}{|c|}{ Predicted } \\
\hline & & \multicolumn{2}{|c|}{ Adoption } & \multirow{2}{*}{$\begin{array}{l}\text { Percentage } \\
\text { corrected }\end{array}$} \\
\hline & & $\mathbf{0}$ & 1 & \\
\hline \multirow[t]{2}{*}{ Adoption } & $\mathbf{0}$ & 23 & 1 & 95.8 \\
\hline & 1 & 3 & 12 & 80.0 \\
\hline \multicolumn{4}{|c|}{ Overall Percentage } & 89.7 \\
\hline
\end{tabular}

Table.9 Result of Logit regression

\begin{tabular}{|c|c|c|c|c|c|c|c|}
\hline \multicolumn{2}{|c|}{ Variables } & B & S.E. & Wald & df & Sig. & $\operatorname{Exp}(B)$ \\
\hline \multirow[t]{8}{*}{ Step $1^{\mathrm{a}}$} & education & .141 & 1.249 & .013 & 1 & .910 & 1.152 \\
\hline & Month of stay & 1.539 & .910 & 2.858 & 1 & .091 & 4.659 \\
\hline & Primary occupation & -11.048 & 6.276 & 3.099 & 1 & .078 & .000 \\
\hline & Migration income & .000 & .000 & .070 & 1 & .791 & 1.000 \\
\hline & Off farm income & .000 & .000 & 2.053 & 1 & .152 & 1.000 \\
\hline & Cropland area & -1.528 & .913 & 2.798 & 1 & .094 & .217 \\
\hline & Technical assistance & -22.449 & 1.941E4 & .000 & 1 & .999 & .000 \\
\hline & Constant & 16.639 & 1.941E4 & .000 & 1 & .999 & 1.684E7 \\
\hline \multicolumn{2}{|l|}{$-2 L L$} & \multicolumn{3}{|c|}{ Cox and Snell R Square } & \multicolumn{3}{|c|}{ Negelkere R Square } \\
\hline \multicolumn{2}{|l|}{$26.624^{\mathrm{a}}$} & \multicolumn{3}{|c|}{6.478} & \multicolumn{3}{|c|}{4} \\
\hline
\end{tabular}




\section{Non CAPS adopted villages}

Result of Final maximum likelihood estimates of frontier production function (Table 5) indicates that coefficient of MOP and area was found to be positive and significantly influence farm output. However associated coefficients of seeds, FYM, DAP, Urea and Labour were not significant at the.10 level of significance and are negatively correlated except Seed which was positively correlated. It can be implied that only MOP among fertilizer and area, positively impacts production of food grain, where as other inputs like DAP, Urea, FYM, Labour don't contribute significantly towards production, due to inefficiency in input uses (Fig. 3).

The value of the sigma square $\left(\delta^{2}\right)$ and gamma (variance ratio) were highly significant indicating good fit and correctness of distributional form composite error term in the model. All the estimated coefficients are less than one, indicating that input allocation is in stage II of the production function.

The estimated coefficient of FYM, DAP, Urea and Labour is negative and nonsignificant indicating that increase in the above inputs doesn't enhance productivity. A summary of the technical efficiency scores for the respondent is presented in Table 7.

Since the Lr test statistics is highly significant the null hypothesis of no inefficiency is rejected. This clearly implied that OLS model is rejected in favor of the stochastic frontier model i.e. there is significant technical inefficiency.

The mean technical Efficiency is 0.52, implying that the farmers were $52 \%$ technically efficient. The best farmer had $99 \%$ technical efficiency while the worst farmer has a technical efficiency of $10 \%$. The minimum values shows the most inefficient farmers and vice versa. If the inefficient farmers enable to achieve the maximum level of efficiency, the cost they may save are up to $89.99 \%$ (1-0.10/0.99). Similarly the normal farmers would enable save $47.47 \%$ of their usual production cost. From the above production function it is clear that the farmers of CAPS adopted villages were more efficient than Non-CAPS adopted villages.

Socio economic determinants of early adopters of hybrid maize using binary Logit model

The results of Logit regression presented in Table 9 shows that only three out of seven predictor variables including cropland area, primary occupation and month of stay were significant at the.10 level of significance. While level of education, migration income, off farm income, technical assistance turned to be non-significant. The $\mathrm{R}^{2}$ of our Logit model was 0.95 indicating that 95 per cent of the variation in the dependent variable was due to changes the selected independent variables. $\operatorname{Exp}(\beta)$ of months of stay in the village was 4.65 , indicating that if the percentage of stay in the village goes up by one unit then the odds of adopting CAPS would also increase. If primary occupation and crop land area increases by one percent the odds of adopting CAPS decreases since $\operatorname{Exp}(\beta)$ is less than 1 . Our data suggests that the remaining four variables do not significantly influence farmer's socio economic behaviors towards adoption of CAPS technology. These findings contradict the findings of Wall (2007), which indicated that level of education was to be positively associated with adoption. Since CAPS technology is capital and labour intensive the adopter has to stay in the village most of the time in order to undertake different types of soil and water conservation measures. Migration and non-farm income appears to discourage adoption of CAPS. 


\section{Constraints identification for CAPS adoption and suggested policy measures}

During the survey work, the following ten constraints were identified which affect adoption of CAPS in the study area, including (1) Input prices are increasing (2) Non availability of labour (3) Non availability of quality seed and other agricultural inputs in time (4) No irrigation scheme (5)) New technology is riskier because of vulnerability to natural calamities. (6) Lack of training and exposure on CAPS (7) Lack of Risk management and insurance coverage (8) Alcoholism and high degree of backwardness (9) Problem of stray cattle and wild animals and (10) Lack of storage, credit and marketing facilities among maize farmers

The percentage score for each rank from 1 to 10 are calculated. The percentage score thus obtained for all the ten ranks are converted into scale values using Scale Conversion Table JINS Joy et al., 2013).

The scale values for first rank to tenth rank are 91, 84, 79, 77, 74, 72, 69, 66 and 64respectively. Non availability of labour was ranked $1^{\text {st }}$ among the 10 constraints of adoption for CAPS. This might be because of: 1) populist scheme like supply of rice @ $2 / \mathrm{kg}$ to persons Below Poverty Line (BPL) dissuades farm labours to work on hiring basis and 2) implementation of MGNREGS (Mahatma Gandhi National Rural Employment Guarantee Scheme) responsible for diverting rural labour force towards nonfarm activities. 3) Migration of labours to urban areas. Further rising input prices ranked as $2^{\text {nd }}$ most important constraint because most of the tribal farmers being resource poor were unable to purchase essential inputs from market in time. Similarly problem of cattle and wild animal followed by lack of insurance coverage ranked $9^{\text {th }}$ and $10^{\text {th }}$ among the constraints respectively.
At present, the lone agricultural university of the state (OUAT) supports $31 \mathrm{KVKs}$ (Krishi Vigyana Kendra/ Farm science centre) and 12 regional research stations across the state, which shows that OUAT has wide network across the state. Thus it can play a major role in promotion of CAPS and replication of CA practices in villages across the State through its KVKs and RRTTS in collaboration with State Government and NGOs. However, due to the prevalence of low yields and food insecurity amongst these smallholder populations, the lack of effectiveness in extension by these research stations for capacity building and information dissemination highlights a disconnect between extension workers and communities. With the pressing need for improved food security and livelihoods for these farmers, policy-makers should enhance the quality of extension services with regards to agriculture technology and knowledge transfer (Lai et al., / IFAMR, Volume 15, Issue 1, 2012).

The Mean Technical Efficiency of CAPS adopted village (Tentuli and Talachampei) was found to be $71.20 \%$ and that of Non CAPS adopted villages (Badamahuladiha and Rudhiapada) was $52.12 \%$, which indicate that the CAPS adopted farmers are $19.08 \%$ more efficient in resource use and cultivation practices than Non CAPS adopted farmers. This is as because CAPS provide intermediate income in between a cropping season through its inter crop (Cowpea), which strengthen farmer's economics and risk bearing ability. $\mathrm{He}$ feels confident to use more qualitative input like seed, labour, FYM etc. On the other hand also due to CAPS practices, fertility of soil increases. So, both of these combinely results in more yield as well as more farm profit to farmers.

The study also reveals that farmers who are staying for longer period in villages and whose primary occupation is mainly farming 
are more likely to adopt CAPS in their crop field. In addition to this, crop land area or holding size is also important determinants in CAPS adoption by farmers due to increase in their risk bearing ability against new practices.

Unavailability of labours in peak seasons and high input cost were found to be the major constraints for adoption of CAPS in North Central Plateau Zone of Odisha. Several populist programmes run by Government and migration of labours to urban areas might be the cause for labour scarcity.

Despite of several constraints for adoption of CAPS, Conservation agriculture doesn't have any alternative especially for fertility and sustainability point of view. Therefore promotion of Conservation Agriculture should be the prime agenda with regards to policy measures towards food security and livelihood of rural households. Among policy measures suggested, coalitions and partnership among institutions that deals with CA viz. State Government, agricultural university (OUAT) and NGOs should work together to promote CAPS in a coordinated way.

\section{Acknowledgement}

The paper was a part of SMARTS (Sustainable management of agro-ecological resources in tribal societies) 2 project going on in Keonjhar in joint collaboration of OUAT, Bhubaneswar, Kinky University, Japan and University of Hawaii, USA. The authors are grateful for all sorts of supports received from the aforesaid project.

\section{References}

Agriculture of Kendujhar District, http://ordistricts.nic.in/important_sector s/index.php?id=15
Aigner, Dennis, Knox Lovell, and Peter Schmidt, "Formulation and estimation of stochastic frontier production function models," Journal of Econometrics, 1977, 6, 21-37

Battese, G.E. and T. Coelli (1992), Frontier production functions, technical efficiency and panel data: with application to paddy farmers in India. Journal of Productivity Analysis, 3, 153-169.

Battese, G.E. and T. Coelli (1995), A model for technical inefficiency effects in a stochastic frontier production function for panel data. Empirical Economics, 20, 325-332.

Battese, G.E., Coelli, T.J., 1988. Prediction of firm-level technical efficiencies with generalized frontier production function for panel data. Journal of Econometrics38, 387-399.

Battese, G.E., Coelli, T.J., 1992. Frontier production functions, technical efficiency and panel data - with applications to paddy farmers in India. Journal of Productivity Analysis 3, 153169.

Battese, G.E., Coelli, T.J., 1995. A model for technical efficiency effects in stochastic frontier production function for panel data. Empirical Economics20, 325-332.

Battese, G.E., Rao, D.S.P., O’Donnell, C.J., 2004. A metafrontier production functionfor estimation of technical efficiencies and technology gaps for firms operating under different technologies. Journal of Productivity Analysis 21, 91-103.

Coelli, T. (1996) A Guide to FRONTIER Version 4.1: A Computer Program for Stochastic Frontier Production and Cost Function Estimation, CEPA Working Paper96/08, http://www.uq.edu.au/ economics/cepa/frontier.htm, University of New England. 
Coelli, T.J., Rao, D.S.P., O’Donnell, C.J., Battese, G.E., 2005. An Introduction to Efficiency and Productivity Analysis, second ed. Springer, New York, USA.

Cornell University College of Agriculture and Life science, Conservation Agriculture: Global Research and Resources. http://conservationagriculture.mannlib.c ornell.edu/, (Assessed, Apr 2015)

Dumanski, J., Peiretti, R., Benetis, J., McGarry, D., and Pieri, C. (2006), 'The paradigm of conservation tillage', Proceedings of World Association of Soil and Water Conservation, Vol 1, pp 58-64.

Erenstein, O. (2002). "Crop residue mulching in tropical and semi-tropical countries: An evaluation of residue availability and other technological implications". Soil and Tillage Research 67(2): 115133.

Farrell, M.J., 1957. The measurement of productive efficiency. Journal of the RoyalStatistical Society 120, 253-281.

Feder, G., Just, R.E. and Zilberman, D., (1985). "Adoption of agricultural Innovations in Developing Countries: A Survey". Economic Development and Cultural change, vol. 33, 255-298.

Frontier Analysis with R, Summer School on Mathematical Methods in Finance and Economy Thibault LAURENT, Toulouse School of Economics June 2010 (slides modified in August 2010)

General information about Odisha. (http://ordistricts.nic.in)
Giller, K. E., E. Witter, et al., (2009). "Conservation agriculture and smallholder farming in Africa: The heretics' view." Field Crops Research 114(1): 23-34.

Information about state geographical and socio economic condition. https://en.wikipedia.org/wiki/Odisha\#G eography

Kassam, A., et al., (2009). "The spread of Conservation Agriculture: justification, sustainability and uptake1." International Journal of Agricultural Sustainability 7: 292-320.

Knowler, D., and Bradshaw, B. (2007), 'Farmers' adoption of conservation agriculture: a review and synthesis of recent research', Food Policy, Vol 32, pp 25-48.

Kumbhakar, S.C., Lovell, C.A.K., 2000. Stochastic Frontier Analysis. Cambridge University Press, Cambridge, UK.

Lavy P.S and Lameshow, S, (1991). Sampling of populations: Methods and Applications, Wiley, New York.

Meeusen, W. and J. van den Broeck (1977), "Efficiency Estimation from CobbDouglas Production Functions with Composed Error", International Economic Review 18, 435-444.

Odisha Economic Survey 2014-15, February 2015 http://dacnet.nic.in/farmer/new/ dac/AgroClimaticZones.asp?SCod=15

\section{How to cite this article:}

Mishra S. N., B. C. Benupani, T. Masuda, U. Mohapatra, P. K. Roul, C. Chan Halbrendt and Shruti Mohapatra. 2018. An Economic Assessment on Conditions for CAPS Adoption in Odisha (India). Int.J.Curr.Microbiol.App.Sci. 7(04): 2932-2946.

doi: https://doi.org/10.20546/ijcmas.2018.704.334 